\title{
호텔기업 중간관리자의 조직몰입-직무가치-직무만족 경합모델 Competitive Models of Organizational Commitment, Work Values and Job Satisfaction of the Middle Management in Hotel Enterprises
}

\author{
박숙진 ${ }^{*}$, 김태헌 ${ }^{* *}$ \\ 한국관광평가연구원, 조선대학교**
}

Suk-Jin Park(mainzpark@hanmial.net)*,Tae-Heon Kim(euro@chosun.ac.kr)**

\section{요약}

본 연구는 호텔기업 중간관리자를 연구대상으로 하여 조직몰입, 직무가치, 직무만족 그리고 충성도에 관 한 실증분석을 시도하고 있다. 즉, 호텔 중간관리자들의 조직에 대한 충성도에 영향을 미치는 매개변수와 독립변수의 경합모형을 개발하여 이론적·실무적 시사점을 도출하는데 연구의 목적이 있다. 분석 결과, 호 텔중간관리자의 직무가치가 조직몰입과 직무만족간의 매개역할을 하지 않고 상호 독립적인 요인으로 작용 하고 있었으며, 직무가치의 경로분석에서는 내재적 가치가 외재적 가치보다 높게 나타났다. 그리고 호텔중 간관리자들은 근속몰입을 하고 있으며 직무에 높은 만족도를 보이고 있음이 확인되었는바, 조직몰입과 충 성도간의 직접적인 경로가 가장 높은 경로계수를 나타내어 깊은 상관관계가 있음이 확인되었다. 그러나 직무만족과 충성도간에는 정 $(+)$ 의 인과관계가 존재하지 않는 것으로 나타났다. 결과적으로 호텔기업 중간 관리자들은 경제적 안정성 때문에 직무몰입과 직무에 만족하기 보다는 전문성으로 대변되는 호텔리어의 내재적 가치에 직장의 의미를 두고 있으며, 조직몰입변수인 평생직장·소속감·자긍심이 인지될 때 충성도에 가장 민감한 영향을 준다는 점을 확인할 수 있었다.

중심어 : | 호텔중간관리자 | 직무만족 | 조직몰입 | 직무가치 | 충성도 |

\section{Abstract}

This study analyzes a correlation between organizational commitment, work values, job satisfaction and loyalty of the middle management in hotel enterprises. In other words, this research aims at drawing up theoretical and working-level implication through establishing the competition model of parameters and independent variables, which have an effect on loyalty of the middle management in hotels. Analysis showed that work values of the middle management play not a key role to mediate between organizational commitment and job satisfaction, and that internal values are higher than external values in route analysis of work values. Meanwhile, it was analyzed that the middle management of hotels make a long-service commitment with great satisfaction on the job. But there was no connection between their job satisfaction and loyalty. Consequently, it was confirmed through the analysis of the competition model that they rather attach significance to internal values and specificity of the hotelier than their satisfaction with work because of economic stability, and the loyalty of the middle management responds sensitively to the organizational commitment variables as a permanent job, sense of belonging, self-esteem.

- keyword : | Hotel's Middle Management | Organizational Commitment | Work Values | Job Satisfaction | Loyalty |

접수번호 : \#110304-004

접수일자 : 2011년 03월 04일
심사완료일 : 2011년 08월 09일

교신저자 : 김태헌, e-mail : euro@chosun.ac.kr 


\section{I. 서 론}

$\mathrm{IMF}$ 이후 유수기업들이 구조조정을 단행하면서 기 업의 중간관리자층 1 은 인원감축 및 직무감축으로 조직 내의 심화된 경쟁체제와 새로운 기업경영환경에 일방 적으로 노출되게 되었다. 이러한 기업구조조정과 함께 기업내 중간관리자층에서도 평생직장이라는 인식이 소 멸되고 소속감과 자긍심이 점감되고 있으며, 직무환경 변화에 따른 개인의 직무가치 또한 변질되고 있는 추세 이다. 즉, 급변하는 직무환경은 직무만족의 정도에 영향 을 미치게 되어 종사원의 직무가치에 대한 기준을 재설 정해야하는 상태에 이르게 되었다.

이와 같은 대내외적 환경 변화 속에서도 호텔기업들 은 '고객은 왕(Customer is King), 고객의 시대(age of Customer)'라는 표어 하에 노사가 단합하여 고객중심 마케팅전략을 구사한 결과, 타 업종과는 다르게 기업퇴 출과 적대적 $\mathrm{M \& A}$ 가 상대적으로 적었으며, 한편으로 가일층 세련된 고품질의 호텔서비스를 보증할 수 있게 되었다. 이러한 호텔기업의 생존권을 담보할 수 있었던 배경에는 타 업종에 비하여 상대적으로 높은 호텔중간 관리자들의 직무가치와 직무 충성도가 매우 긍정적으 로 작용하였기 때문인 것으로 사료된다. 즉, 호텔기업 조직내에서의 고무된 직무가치와 자긍심은 단순한 개 인의 가변성 가치차원을 넘어 호텔직무만족과 호텔기 업조직에 대한 중간관리자의 충성도에 영향을 미치는 중요한 변수가 되기 때문이다. 이 처럼 다변적 특성과 황금만능주의가 만연한 현대사회에서의 직무가치는 가 치 중심적 사고를 지닌 중간관리자들에 의해 조직의 변 혁과 경영형태의 변화를 가져다 줄 수 있는 중요한 요 소로 작용할 수 있다.

그러나 국내의 호텔산업분야에 대한 연구동향을 살 펴볼 때, 조직몰입이나 직무만족을 조직유효성 평가 변 수로 설정하고 충성도의 영향관계를 알아보기 위한 연 구들은 많이 있지만[5-7][10][11], 직무가치를 매개변수

1. 중간관리자층(the middle management)은 기업의 최고관리자층(the top management)과 현장감독자층(the lower management)의 중간 에 위치한 직능부문 운영에 책임을 맡은 과장, 차장, 부장급 관리자 를 총칭하지만, 본 연구에서는 5년차 대리급 매니저도 중간관리자층 에 포함시켜 분석하고 있음.
로 설정한 연구나 독립변수로 구성하여 심도 있게 분석 한 연구[3][4]는 상대적으로 저조한 실정이다.

이에 본고에서는 호텔기업 중간관리자를 연구대상으 로 하여 조직몰입, 직무가치, 직무만족 그리고 충성도에 관한 실증분석을 시도하고자 한다. 즉 호텔 중간관리자 들의 직무만족도 과정을 모델링하기 위해 직무가치를 매개변수와 독립변수의 경합모델로 구성하여 직무가치 의 역할을 규명한 후, 호텔기업경영에 중요시되고 있는 직무가치에 관한 최종 모델을 수립하여 이론적·실무적 시사점을 제시하고자 한다.

\section{II. 이론적 배경}

\section{1. 직무만족의 조직몰입-직무가치 모델}

\section{1 직무만족}

직무만족의 정의와 관련하여 김대권[2]은 직무에 긍 정적, 부정적으로 느끼는 정도이고, 종사원들이 수행하 는 과업과 물리적-사회적 조건에 대한 감정적 반응 혹 은 태도를 의미한다고 보았으며, 오동근[9]은 직무만족 을 직무자체 또는 직무 상황들에 대한 개인의 평가적 판단이라고 정의하였다. 한편, Locke[21]는 직무만족을 직무경험에 대한 평가로 얻어지는 만족의 정도라고 정 의하고 이 개념은 종업원이 느끼는 심리적인 측면보다 는 그들이 직무결과를 통해 얻을 수 있는 보상적 측면 을 강조하고 있다고 주장하였다. 이와 같이, 직무만족은 각 개인이 직무를 수행하면서 느끼고 감지하는 개인의 만족정도를 나타낸 것으로 종사원이 느끼는 만족정도 는 개인의 능력과 자질, 수행하고 있는 업무에 대한 적 응력, 다양한 조직 내부환경과 절대적인 관계가 있다 [12]. 이에 연유하여 Cellucci과 DeVries [18]는 직무만 족 설문측정항목을 업무, 급료, 승진, 동료, 상사로 분류 하였고 함성필과 손선익[15]은 근로환경과 동기부여 요 인으로 구분하고 주방업무, 근무분위기, 업무량, 인사고 과, 급여 등의 측정항목을 두었다.

이상의 관점에서 직무만족에 대한 개념을 종합해보 면 직무만족의 중심개념은 직무상 욕구충족여부, 직무 자체의 특성 및 직무주변 환경과 관련된 태도[5]와 밀 
접한 관계가 있음을 확인할 수 있다.

\section{2 조직몰입}

조직몰입은 조직에 대한 강한 일체감과 참여의지, 자 발적인 노력과 조직 구속력으로 나타나며[40], 목표와 가치에 대한 강한 신념과 조직을 위해 상응하는 노력을 하고자 하는 의지와 조직구성원으로 남기를 바라는 강 한 욕구로 대변될 수 있다. 이에는 보상을 기대하는 계 산적 측면과 개인의 가치관이 조직의 목적, 정책 및 업 무와 일체감을 느끼는 도덕적 측면이 내재되어 있다 [34]. 함성필과 손선익[8]은 조직몰입이란 조직구성원 이 조직에 대해 정서적 애착심과 충성심을 가지고 조직 의 목표와 가치에 자신의 목표와 가치를 동일시함으로 써 자신의 작업 활동에 열중하며 조직의 구성원으로 남 으려는 의지 또는 욕구라고 정의하였다. 또한 Glisson 과 Durick[19]는 호텔종사원이 조직몰입에 미치는 영향 관계에서 조직몰입은 근속기간과 상관관계가 있으며 장기 근속자에게서 조직몰입 성향이 높게 나타나는 것 으로 주장하고 있다. Meyer와 Allen[27]은 조직몰입을 정서적 몰입, 지속적 몰입, 규범적 몰입으로 구분한 반 면, 함성필과 손선익[15]은 근속몰입, 규범몰입, 도덕몰 입, 행위몰입, 네 가지로 구분하고 있다. 결국 조직몰입 은 조직목표 및 가치관과 관련된 조직의 역할, 조직 자 체에 대한 열렬한 애착이라 정의[16]할 수 있으며, 정서 몰입, 근속몰입, 규범몰입의 세 가지 형태로 구분[39]할 수 있다.

이상의 선행연구를 종합해 볼 때, 호텔기업에서의 조 직몰입은 조직의 직무환경에서 찾을 수 있으며 내부종 사자가 자신의 조직에 대해 신뢰를 가지고 직무에 긍정 적 태도를 형성할 때 조직에 몰입하게 되며 만족하게 되고 현재의 일을 지속하고자하는 노력과 함께 충성심 이 강화되는 것으로 볼 수 있다.

\section{3 직무가치}

직무가치란 한 개인이 자신의 직무를 통하여 바라는 궁극적인 목표를 의미한다. 즉 조직구성원의 개인적 사 고인 직무가치는 직무에 대한 신념 및 선호의 정도라는 점에서 전통적으로 조직구성원의 행동을 예측하는데
있어서 매우 중요한 변수로 사용되어 왔다[20]. 또한 탐 색적 연구를 통해 직무가치를 개념화한 이지우[14]는 자신의 직무를 통해 가지는 자부심과 긍지를 느낄 수 있는 기회, 조직에 관심을 갖고 여러 가지 활동에 적극 적으로 참여하며 원만한 인간관계를 형성하고 유지하 려는 자세, 그리고 적극적이며 활동적으로 일 할 수 있 는 기회 등이 직무가치를 업그레이드 시키는 주요인이 라고 분석하였다.

직무가치를 분류한 선행연구를 분석해 보면, 김영훈 [3][4]은 직무가치를 내재적 가치와 외재적 가치 그리고 부수적 가치로 분류하고, 내재적 가치는 전문성, 외재적 가치는 경제적 안정, 인정감, 개인생활, 그리고 부수적 가치는 본부와의 관계와 밀접한 관련이 있는 것으로 보 았다. Elizur와 Koslowsky[20]는 직무가치를 내재적 지 향가치와 외재적 지향가치로 분류하고 내재적 직무가 치는 직무자체에 대한 고유한 가치를 의미하며, 외재적 가치는 업무활동에 따른 보상과 관련한 가치를 의미한 다고 주장하고 있다.

이러한 연구결과들을 토대로 직무가치를 정의하면, 개인은 자기 자신에 대해 가지는 태도와 일치하는 방향 으로 일에 대한 태도와 행동을 보이는 것[3]으로 개념 지을 수 있다. 특히 호텔 중간관리자의 경우 자신의 업 무에서 경험하게 되는 높은 신뢰도와 긍정적인 심리상 태에서 개인의 내재적 가치는 자극받게 되고 직무에 몰 입하면서 외재적 가치에서 보상받기를 기대하는 것으 로 정리할 수 있다.

\section{4 충성도}

최근의 연구경향들은 제품이나 브랜드의 재구매 현 상을 고객충성도의 시각에서 포괄적으로 다루고 있는 바, Keller[31]는 충성도란 선호하는 제품이나 서비스를 재구매하거나 단골고객이 되려는 깊은 몰입상태이며, 제품에 대하여 만족도를 느끼면 다시 방문하게 되며 더 나아가서 긍정적인 구전행위를 하는 등의 충성도를 나 타내는 것[8]으로 정의하고 있다. 한편 조직 구성원의 조직에 대한 충성도도 이와 유사한 경향을 보인다. 조 직구성원은 직무가치를 높게 평가할 경우 행복감을 느 끼고 그 행복감이 증가할수록 무드 동화효과(mood- 
based assimilation)[13]가 발생하는데, 결국 이는 조직 에 대한 충성도를 증가시키는 경향이 있다. 이러한 연 구결과들을 확인해 볼 때, 조직충성도는 행동주의적 시 각에서 직무몰입과 연계되며, 인지적 직무만족과 직무 가치 향상에 영향을 받는 것으로 볼 수 있다.

\section{2. 직무만족에 대한 경합모델}

직무가치-직무만족간의 영향관계에 관한 기존연구 를 살펴보건대, Knoop[38]는 직무자체, 임금, 승진기회, 감독, 동료 등 직무가치가 직무만족에 미치는 영향을 분석하였는바, 직무가치 영역에서의 성취감이 직무만 족에 가장 큰 영향력을 행사한다는 것을 확인하였다. 이러한 종사원의 직무만족은 기업의 성공적 경영과 고 품질 서비스 제공을 위한 중요한 요소로서 높은 수익성 과 생산성을 유발시킨다[36]. 또한 종사원이 직무가치 에 의해 성취감을 느끼게 되면 좋은 감정 상태에서 직 무만족을 평가하게 되고 직무만족에 대한 만족도가 높 은 구성원은 자신의 직무환경에 긍정적 태도를 취하는 동시에 조직에 대한 높은 충성도를 보이고 이직 의도는 상대적으로 감소된다[17].

이상과 같은 관점에서 직무만족의 조직몰입-직무가 치간의 관계는 조직몰입에서 느끼는 감정적 현상과 경 험적 특징에 의해서 지각된 느낌을 만족으로 표현하고 조직내에서 충성도를 발휘하는 것으로 볼 수 있다.

\section{1 조직몰입과 직무만족간 매개변수로서의 직무가치}

직무가치, 조직몰입, 직무만족과 관련된 연구에서 조 직몰입이 직무만족의 선행변수가 되며[6][10][11][17], 직무가치는 직무만족과 직무몰입의 선행변수의 관계에 있다[3]. 따라서 직무가치는 한 개인이 자신의 직무를 통하여 보상받고자하는 궁극적인 목표, 신념 및 선호의 정도로 조직구성원의 행동을 예측하는데 있어서 매우 중요한 변수라 할 수 있다[20].

이러한 관점에서 직무가치가 조직몰입과 직무만족 사이에서 어떠한 영향을 미칠 것인지를 분석하는 것은 현대사회의 기업조직에 큰 의미가 있을 것으로 예상된 다. 특히 직무가치가 조직몰입과 직무만족간에 매개역 할을 할 것이라는 가정하에 호텔기업을 대상으로 분석
하는 것은 자못 유의미하다 하겠다.

\section{2 조직몰입과 직무만족간 독립변수로서의 직무가치}

Hackman과 Oldham[28]은 인간은 자신이 하는 일이 의미 있고, 가치 있고, 보람 있는 일이라고 지각하게 되 면 일에 대한 만족감이 향상된다고 보았다. 또한 종사 원이 직무가치에 의해 성취감을 느끼게 되면 높은 직무 만족을 보이며, 직무만족도가 높은 구성원은 자신의 직 무환경에 긍정적 태도를 취하는 직무몰입의 경향을 보 이게 된다[5]. 한편 김영훈[3]은 직무가치가 직무효과성 에 미치는 영향에 관한 연구에서 독립변수로서의 직무 가치가 직무만족에 유의한 영향을 준다는 것을 입증하 였다.

이러한 관점에서 직무가치는 개인이 직무에 대한 신 념과 일치하는 방향으로 자신의 일에 대한 태도와 행동 에 가치를 부여할 것이므로 직무만족에 독립변수로 존 재할 것으로 예측할 수 있다. 특히 인적서비스의 특성 이 가장 강하게 나타나는 호텔기업이라는 독특한 인적 자원 관리시스템에서 호텔인사조직 구성원들이 지각하 는 직무가치가 독립적인 요인을 보일 것인지 확인하는 것 역시 중요하다 하겠다.

\section{III. 연구설계}

\section{1. 연구모형}

본 연구모형은 직무만족에 관한 경쟁모델로 직무가 치의 역할을 두 가지의 방법 즉 매개효과와 독립변수효 과로 나누어 분석하는 연구모형이다. 모든 변수들간의 인과관계는 정(+)의 관계로 비교 가능한 조건[1][33]으 로 가정되었다.

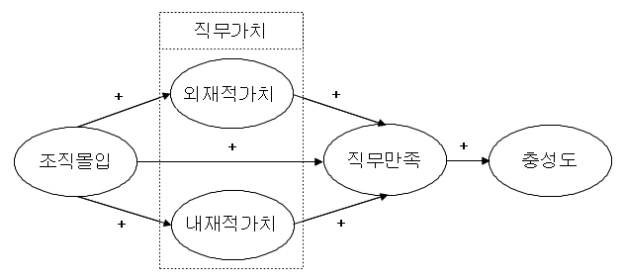

그림 1. 연구모형 | 


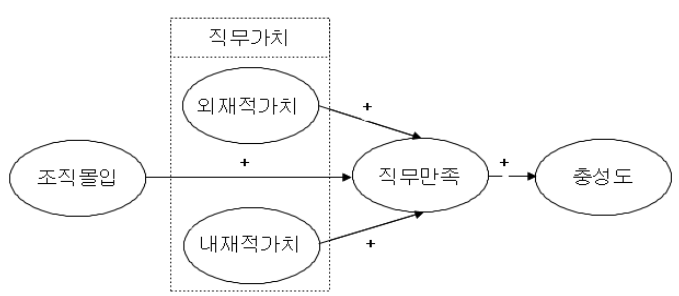

그림 2. 연구모형 ॥

\section{2. 변수의 조작적 정의 및 설문지 구성}

선행 연구결과를 검토해 본 결과 변수의 상세 항목으 로 구성된 측정변수라 하더라도 구체적으로 살펴보면, 학문간의 특성에 따라 하부개념이 다른 경우도 나타났 다. 따라서 개념에 대한 혼란과 일관성 문제에서 접목 의 기준을 수립할 필요가 있다. 따라서 호텔기업의 특 성에 준하여 사용되어야 될 기준변수를 변수의 조작적 정의를 통해 구체화하여 [표 1]에 정리하였다.

\section{표 1. 설문지 구성}

\begin{tabular}{|c|c|c|c|c|}
\hline \multicolumn{2}{|c|}{ 변수 } & 측정항목 & 측정변수의 조작적 정의 & 관련연구 \\
\hline \multirow{3}{*}{\multicolumn{2}{|c|}{ 조직몰입 }} & 01 & 호텔서비스 기업 소속감 & \multirow{3}{*}{$\begin{array}{c}{[34][15][19]} \\
{[16][39]}\end{array}$} \\
\hline & & $\mathrm{O} 2$ & 호텔맨의 자긍심 & \\
\hline & & $\mathrm{O} 3$ & 호텔기업은 평생직장 & \\
\hline \multirow{6}{*}{$\begin{array}{l}\text { 직무 } \\
\text { 가치 }\end{array}$} & \multirow{3}{*}{$\begin{array}{l}\text { 외재적 } \\
\text { 가치 }\end{array}$} & L1 & 상사-칭찬과 인정 & \multirow{6}{*}[20]{$[3][4]$} \\
\hline & & L2 & 동료-칭찬과 인정 & \\
\hline & & L3 & 고객-칭찬과 인정 & \\
\hline & \multirow{3}{*}{$\begin{array}{l}\text { 내재적 } \\
\text { 가치 }\end{array}$} & S1 & 호텔 전문가로 성장 & \\
\hline & & S2 & 호텔 전문능력 요구 & \\
\hline & & S3 & 자신의 필요성 & \\
\hline \multirow{3}{*}{\multicolumn{2}{|c|}{ 직무만족 }} & M1 & 업무만족 & \multirow{3}{*}{$\begin{array}{c}{[9][21][18]} \\
{[15]}\end{array}$} \\
\hline & & M2 & 급여만족 & \\
\hline & & M3 & 승진만족 & \\
\hline \multirow{3}{*}{\multicolumn{2}{|c|}{ 충성도 }} & J1 & 충성심 & \multirow{3}{*}{$\begin{array}{c}{[31][8][13]} \\
{[5]}\end{array}$} \\
\hline & & $\mathrm{J} 2$ & 호텔기업 취업홍보 & \\
\hline & & J3 & 직무몰입 & \\
\hline
\end{tabular}

조직몰입은 조직에 대한 강한 일체감과 참여의지, 자 발적인 노력과 조직 구속력[40]으로 정의되며, 기존연 구[15][16][19][34][39]를 참고하여 호텔기업의 특성에 부합하는 3 개의 항목으로 구성하였다. 직무가치는 한 개인의 직무 목표와 신념이며 조직구성원의 행동 예측 변수이다. 직무가치를 분류한 선행연구[3][4][20]를 참 고로 호텔리어의 특성을 반영하여 각 각 3 개 항목으로 구성하였다. 그리고 직무만족은 각 개인이 조직내에서 직무를 수행하면서 느끼고 감지하는 개인의 만족정도
를 나타낸 것[12]으로, 기존연구[9][15][18][21]의 측정 항목을 반영하여 3개 항목으로 구성하였다. 한편, 충성 도는 단골고객이 되려는 깊은 몰입상태로 선행연구 [5][8][13][31]를 호텔기업에 접목하여 3개의 문항으로 구성하였다.

\section{4. 조사설계 및 연구방법}

본 연구를 위한 설문조사는 2010년 10 월 1 일부터 10 월 30 일 까지 1 개월 동안 서울시내 특급 호텔 중간관리 자를 대상으로 한국관광평가연구원의 조사 시스템에 의해 수행되었다. 설문지는 280 부를 배포하였으나 이중 일관성이 떨어지는 설문지 4 부를 제외하고 276 부를 분 석에 활용하였다. 설문형식은 자기기입식 방법과 5점 리커트 방식으로 표기하도록 하였으며 인구 통계적 항 목은 명목척도로 구성하였다. 분석은 SPSS/PC 15.0과 AMOS 6.0을 활용하여 실시하였다.

\section{IV. 실증분석}

\section{1. 표본의 일반적 특성}

본 연구에 참여한 총 276 명의 설문응답자들 중 남성 은 $62.7 \%$, 여성은 $37.3 \%$ 로 나타났고, 나이는 30-39세가 $43.2 \%$ 로 가장 많았다. 학력은 대졸이 $60.9 \%$, 대학원졸 이상이 $39.1 \%$ 로 나타났으며, 근무부서로는 연회장 및 식음료(주방포함)가 $57.6 \%$ 로 가장 많았고 객실부서가 $24.2 \%$, 그리고 프론트데스크 $9.8 \%$, 휘트니스센터 $8.4 \%$ 순으로 집계되었다. 근무경력은 7-9년이 42.3\%로 가장 많았고 10-12년이 26.5\%, 4-6년이 24\%, 12년 이상이 $7.2 \%$ 순으로 나타났다.

\section{표 2. 표본의 일반적 특성 $(n=276)$}

\begin{tabular}{|c|l|r|c|}
\hline \multicolumn{2}{|c|}{ 구분 } & 빈도 & 비율(\%) \\
\hline \hline \multirow{2}{*}{ 성별 } & 남성 & 173 & 62.7 \\
\cline { 2 - 4 } & 여성 & 103 & 37.3 \\
\hline \multirow{3}{*}{ 나이 } & 20-29세 & 76 & 27.5 \\
\cline { 2 - 4 } & $30-39$ 세 & 119 & 43.2 \\
\cline { 2 - 4 } & 40세 이상 & 81 & 29.3 \\
\hline \multirow{2}{*}{ 학력 } & 대졸 & 168 & 60.9 \\
\cline { 2 - 4 } & 대학원이상 & 108 & 39.1 \\
\hline 근무부서 & 프런트데스크 & 23 & 8.4 \\
\hline
\end{tabular}




\begin{tabular}{|c|l|r|r|}
\hline \multirow{5}{*}{} & 연회장 및 식음료(주방) & 159 & 57.6 \\
\cline { 2 - 4 } & 객실 & 67 & 24.2 \\
\cline { 2 - 4 } & 휘트니스센터 & 27 & 9.8 \\
\hline \multirow{4}{*}{ 근무경력 } & 4-6년 & 66 & 24.0 \\
\cline { 2 - 4 } & $7-9$ 년 & 117 & 42.3 \\
\cline { 2 - 4 } & $10-12$ 년 & 73 & 26.5 \\
\cline { 2 - 4 } & 12년 이상 & 20 & 7.2 \\
\hline
\end{tabular}

주: 본 분석에서는 조사대상의 소속호텔, 직급, 연봉 등이 배제되었음.

\section{2. 타당성 및 신뢰성 검증}

전체 측정변수의 타당성 검증을 위한 요인부하량은 0.50 이상으로 나타나 통계적으로 유의미함[25]이 확인 됨에 따라 전체 항목이 활용되었다. 최근 적합도 정도 를 판단하는데 있어 선호되고 있는 지수는 $\mathrm{CFI}$ 와 DELTA2[29], RMR GFI 등이며, 특히 RMSEA와 chi-square의 검증을 통하여 완전한 모델평가를 수행 할 수 있다고 주장[26][32]한다. 지수의 기준치는 CFI $>0.90, \quad$ RMSEA $<0.08[32], \quad$ DELTA2 $>0.95[30]$, $\mathrm{CMIN} / \mathrm{DF}<3[1]$ 값을 추천[37]하고 있다.

\section{표 3. 측정변수의 요인부하량}

\begin{tabular}{|c|c|c|c|c|c|}
\hline 변수 & $\begin{array}{l}\text { 측정 } \\
\text { 항복 }\end{array}$ & $\begin{array}{l}\text { 경로 } \\
\text { 계수 }\end{array}$ & $\begin{array}{l}\text { 표준 } \\
\text { 오차 }\end{array}$ & $\begin{array}{c}\text { 표준화 } \\
\text { 경로계수 }\end{array}$ & C.R. \\
\hline \multirow{3}{*}{$\begin{array}{l}\text { 조직 } \\
\text { 몰입 }\end{array}$} & O3 & 1.000 & - & .856 & - \\
\hline & $\mathrm{O} 2$ & .998 & .052 & .889 & 19.252 \\
\hline & 01 & .997 & .056 & .852 & 17.949 \\
\hline \multirow{3}{*}{$\begin{array}{l}\text { 외재적 } \\
\text { 가치 }\end{array}$} & L3 & 1.000 & - & .825 & - \\
\hline & L2 & 1.135 & .069 & .821 & 16.367 \\
\hline & L1 & 1.390 & .073 & .961 & 18.941 \\
\hline \multirow{3}{*}{$\begin{array}{l}\text { 내재적 } \\
\text { 가치 }\end{array}$} & $\mathrm{S} 1$ & 1.000 & - & .743 & - \\
\hline & S2 & .901 & .107 & .801 & 8.429 \\
\hline & S3 & 1.027 & .107 & .716 & 9.599 \\
\hline \multirow{3}{*}{$\begin{array}{l}\text { 직무 } \\
\text { 만족 }\end{array}$} & M3 & 1.000 & - & .746 & - \\
\hline & M2 & 1.153 & .101 & .741 & 11.480 \\
\hline & M1 & 1.063 & .101 & .664 & 9.973 \\
\hline \multirow{3}{*}{ 충성도 } & $\mathrm{J1}$ & 1.000 & - & .717 & - \\
\hline & $\mathrm{J} 2$ & 1.153 & .117 & .793 & 8.532 \\
\hline & J3 & 1.063 & .127 & .727 & 9.952 \\
\hline \multicolumn{6}{|c|}{$\begin{array}{l}2 / \mathrm{df}=184.801(80), p<0.001, \mathrm{RMR}=0.029, \mathrm{GFI}=0.922, \\
\mathrm{RMSEA}=0.069, \mathrm{CF}=0.953, \mathrm{DELTA}=0.953, \mathrm{CM} / \mathrm{D} / \mathrm{DF}=2.310\end{array}$} \\
\hline
\end{tabular}

주: 표준화계수를 추정하기 위해 1 로 지정함.

본 연구의 적합도 평가결과, $\mathrm{CFI}=0.953$, DELTA2= 0.953, RMR=0.029, GFI $=0.922, \quad \mathrm{X}^{2} / \mathrm{df}=184.801(80)$, $\mathrm{p}<0.001, \mathrm{RMSEA}=0.069, \mathrm{CMIN} / \mathrm{DF}=2.310$ 으로 나타나 통계적으로 타당성이 확보되었다. 여기서는 변수간 타 당성을 검증하는 방법으로 평균분산추출값(AVE)을 비 교하고, 두 잠재요인 간의 상관관계 제곱값을 비교하였
다. Hair와 Anderson과 Tatham과 Black[25]에 의하면 $\mathrm{AVE}$ 값은 0.5 이상이거나 상관관계 제곱값을 상회할 경우에는 판별타당성이 있는 것으로 본다.

\section{표 4. 상관관계 행렬}

\begin{tabular}{|c|c|c|c|c|c|}
\hline \multirow[b]{2}{*}{ 변수 } & \multirow{2}{*}{$\begin{array}{l}\text { 직무 } \\
\text { 몰입 }\end{array}$} & \multicolumn{2}{|c|}{ 직무가치 } & \multirow{2}{*}{$\begin{array}{l}\text { 직무 } \\
\text { 만족 }\end{array}$} & \multirow[b]{2}{*}{ 충성도 } \\
\hline & & $\begin{array}{l}\text { 외재적 } \\
\text { 가치 }\end{array}$ & $\begin{array}{c}\text { 내재적 } \\
\text { 가치 }\end{array}$ & & \\
\hline 조직몰입 & .750 & .154 & .254 & .440 & .475 \\
\hline 외재적가치 & .392 & .760 & .195 & .227 & .222 \\
\hline 내재적가치 & .504 & .441 & .569 & .424 & .452 \\
\hline 직무만족 & .663 & .476 & .651 & .516 & .379 \\
\hline 충성도 & .689 & .471 & .672 & .615 & .558 \\
\hline 신뢰도 & .899 & .719 & .901 & .772 & .766 \\
\hline
\end{tabular}

주: 모든 상관계수는 $p<0.001$ 에서 유의함.

대각선 셀의 숫자: 평균분산추출값(AVE)

대각선 아래: 상관계수( $r)$, 대각선 위: 상관관계 제곱 $\left(r^{2}\right)$

본 연구는 [표 4]에 제시된 바와 같이 상기조건을 모 두 충족하여 집중타당성과 판별타당성이 있음을 확인 하였다. 또한 신뢰도 검증에서는 Nurosis[35]가 제시한 것과 같이 전체 상관계수가 0.30 이상으로 나타났고, Cronbach's alfa는 Nunnally의 주장[23]과 같이 0.70 이 상을 보여 신뢰도가 확보되었다.

\section{3. 경합모형 분석}

본 분석은 직무가치, 직무만족의 경합모형 평가과정 으로 두 모형간의 경로 감소를 통하여 직무가치요인이 직무만족에 미치는 영향관계를 살펴보고 매개변수와 독립변수로서의 역할을 파악하는 데에 의미가 있다. 두 경합모형의 경로분석 결과는 [그림3]과 [그림4]에 제시 하였다. 두 모형간 표준화 경로계수를 통하여 검증한 결과, 모든 경로에서 통계적으로 유의한 것으로 분석되 었다.

Anderson과 Gerbing[22]은 경합모형의 평가과정에 서 두 개의 모형이 nested(중첩) 관계에 있으면 chi-square차이 검증을 통하여 모델을 선택할 것을 권 장하고 있으며, 이때 간명적합도지수를 추가적으로 검 증해야 한다고 부연[33]하고 있다. 


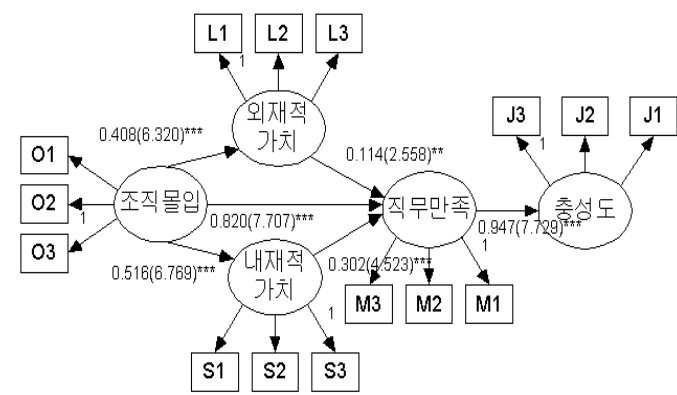

주: *: $\mathrm{p}={ }^{* *}: \mathrm{p}\left\langle 0.05,{ }^{* * *}: \mathrm{p}<0.01\right.$

$\rightarrow$ 통계적으로 유의한 경로/표준화경로계수(t값)

그림 3. 경합모형 ।

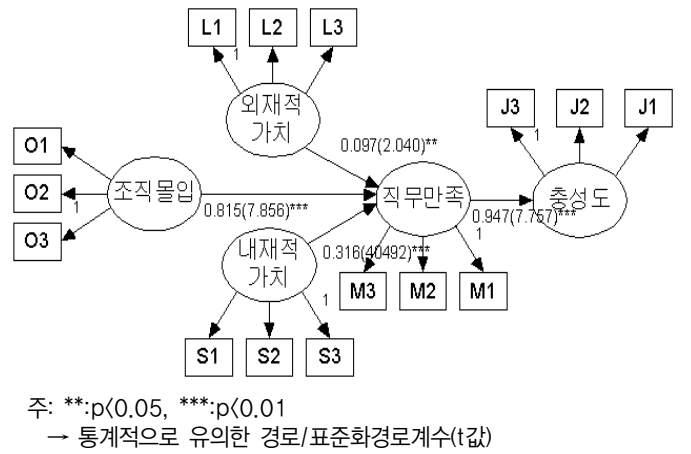

그림 4. 경합모형 ॥

본 경합모형의 검증결과는 [표 5]과 같다. 경합모형I 과 경합모형II는 nested(중첩) 관계에 있으므로 $\mathrm{x}^{2}$ 검증 을 통하여 비교할 수 있는데, 두 모형간 chi-square차 이는 중요한 변화를 보여주고 있다 $\left(\Delta x^{2}=15.229>x^{2}{ }^{2} 05\right.$ (1)=3.841, $\Delta$ d.f.=1). 즉 경합모형II는 경합모형I에 비해 자유도가 1 만큼 감소하였으나, $x^{2}$ 값의 감소폭이 자유 도 감소를 상쇄시킬 만큼 충분히 감소했으므로 경합모 형II가 더 우수한 것으로 나타났다.

[표 5]은 또 다른 평가방법을 제시하고 있는데, 경합 모형II는 모형I 보다 RMSEA $(0.81 \leftarrow 0.84), \mathrm{CFI}(0.934 \leftarrow$ $0.928)), \quad$ DELTA2 $(0.935 \leftarrow 0.928), \quad$ GFI $(0.905 \leftarrow 0.898)$, $\operatorname{RMR}(0.039 \leftarrow 0.050)$ 에서 더 향상된 적합도를 보이고 있 다. 또한 Caro와 Garcia[33]와 Hair와 Anderson \& Tatham과 Black[25]는 간명적합도 지수검증에서 AIC 와 $\mathrm{PNFI}$ 의 비교를 적극 권장하고 있다. $\mathrm{AIC}$ 검증 비교 결과, 경합모형(이.153)는 경합모형I(317.452) 보다
감소되었으며, 두 모델간 PNFI (0.699 - 0.676)는 증가 되어 경합모형II가 우수한 모델로 입증되었다.

\section{표 5. 경합모형의 통계지수}

\begin{tabular}{|c|c|c|c|c|}
\hline 모델 & 적합도기준치 & 경합 Mdel I & 경합 Modl II & $\begin{array}{c}\text { 최종경합 } \\
\text { Model }\end{array}$ \\
\hline \hline $\mathrm{X}^{2}$ & - & 241.452 & 226.153 & 205.426 \\
\hline $\mathrm{df}$ & - & 82 & 81 & 80 \\
\hline $\mathrm{RMSEA}$ & $\langle .08$ & .084 & .081 & .076 \\
\hline $\mathrm{CFI}$ & $\succ .90$ & .928 & .934 & .943 \\
\hline DELTA2 & $\succ .95$ & .928 & .935 & .944 \\
\hline $\mathrm{GFI}$ & - & .898 & .905 & .912 \\
\hline $\mathrm{RMR}$ & $\langle .05$ & .050 & .039 & .032 \\
\hline $\mathrm{CMIN} / \mathrm{DF}$ & $\langle 3$ & 2.945 & 2.792 & 2.568 \\
\hline $\mathrm{AIC}$ & - & 317.452 & 304.153 & 285.426 \\
\hline $\mathrm{PNFI}$ & - & .676 & .699 & .694 \\
\hline
\end{tabular}

또한 Caro와 Garcia는 경합모형의 경쟁적 우수 모델 선정에서 수정지수를 통한 최종 모델을 선정할 것 [1][33]을 권고하고 있다. 본 모형에서도 직무몰입과 충 성도간의 새로운 경로를 발견하고 긍정적이며 유의한 직접경로를 설정하였다. 이와 같은 검증을 통하여 본 연구는 최종모델을 선정하였으며 전체적인 검증 지수 는 [표 5]에 제시하였다.

결과적으로, 내재적 가치와 외재적 가치는 독립변수 로서 관측된 데이터를 더 잘 반영하고 있다. 또한 조직 몰입과 충성도간의 직접경로 설정은 Caro와 Garcia [33]와 Bigne와 Andreu[24]의 연구를 지지하고 있으며, 서비스를 강화하기 위해 실행하는 조직몰입의 의도적 행위는 충성도에 긍정적인 영향을 미칠 수 있다는 것 [33]을 나타내 주고 있다.

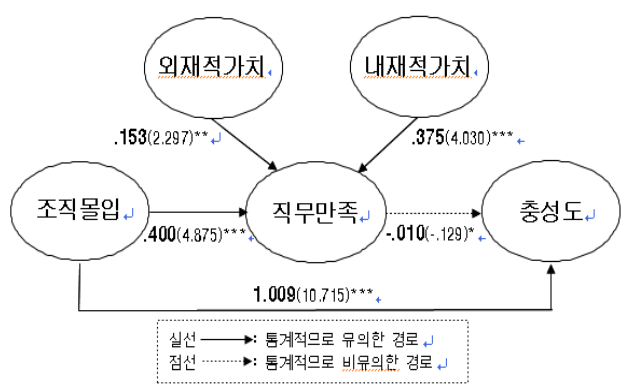

그림 5. 최종 모델 
표 6. 최종모델의 경로과정

\begin{tabular}{|c|c|c|c|c|c|}
\hline 경로 & \multicolumn{1}{|c}{ 경로방향 } & $\begin{array}{c}\text { 경로계수 } \\
\text { (표준오차) }\end{array}$ & $\begin{array}{c}\text { 표준화 } \\
\text { 경로계수 }\end{array}$ & $\begin{array}{c}\text { t값 } \\
(p \text { 값) }\end{array}$ & 결과 \\
\hline \hline 1 & $\begin{array}{c}\text { 직무만족 } \\
\text { 외재적 가치 }\end{array}$ & $\begin{array}{c}.096 \\
(.042)\end{array}$ & .153 & $\begin{array}{c}2.297 \\
(* *)\end{array}$ & 채택 \\
\hline 2 & $\begin{array}{c}\text { 직무만존 } \\
\text { —내재적 가치 }\end{array}$ & $\begin{array}{c}.418 . \\
(.104)\end{array}$ & .375 & $\begin{array}{c}4.030 \\
(* *)\end{array}$ & 채택 \\
\hline 3 & $\begin{array}{c}\text { 직무만족 } \\
\text { 조직몰입 }\end{array}$ & $\begin{array}{c}.364 \\
(.075)\end{array}$ & .400 & $\begin{array}{c}4.875 \\
(* *)\end{array}$ & 채택 \\
\hline 4 & $\begin{array}{c}\text { 충성도 } \\
\text { 직무만족 }\end{array}$ & $\begin{array}{c}-.009 \\
(.068)\end{array}$ & -.010 & $\begin{array}{c}-.129 \\
(*)\end{array}$ & 기각 \\
\hline 5 & $\begin{array}{c}\text { 충성도 } \\
\text { 조직몰입 }\end{array}$ & $\begin{array}{c}.803 \\
(.075)\end{array}$ & 1.009 & $\begin{array}{c}10.715 \\
(* *)\end{array}$ & 채 택 \\
\hline
\end{tabular}

주: ${ }^{*}: p=0.897,{ }^{* *}: p<0.05,{ }^{* * *}: p<0.01$

결과적으로 조직몰입과 외재적 가치 그리고 내재적 가치는 직무만족에 긍정적이며 유의한 영향관계를 나 타내고 있으며, 조직몰입은 외재적 가치와 내재적 가치 보다 직무만족에 더 강하게 영향을 미치고 있다는 것이 입증되었다. 또한 직무만족과 충성도에 관한 정(+)의 인과관계는 기각되었으며 상대적으로 조직몰입과 충성 도의 직접적인 관계가 채택되었고 가장 강한 영향력이 있음을 확인하였다.

\section{V. 논의 및 시사점}

직무가치의 새로운 모델개발을 목적으로 본 연구에 서는 호텔중간관리자가 자신의 업무를 수행하면서 지 각하는 직무가치를 매개변수와 독립변수로 분류하여 상호 경합모형으로 설정하였다. 그에 따라 호텔중간관 리자를 대상으로 조직몰입, 직무가치, 직무만족 그리고 충성도에 관한 영향관계에 대하여 실증 분석하였는바, 분석결과는 다음과 같다.

첫째, 경합모형 테스트 결과 경합모형II가 우수한 것 으로 나타남으로써 호텔중간관리자의 직무가치가 조직 몰입과 직무만족에 매개역할을 하기보다는 독립적인 요인으로 작용하고 있음이 밝혀졌다.

둘째, 호텔중간관리자의 직무가치 경로분석에서 내 재적 가치는 외재적 가치보다 높게 나타났는바, 이는 몇몇 선행연구의 결과[3][4]를 지지하고 있다.

셋째, 호텔중간관리자의 조직몰입과 직무만족 간의
정(+)의 인과관계는 상대적으로 높은 경로계수를 보임 으로써 일부 연구[3]와는 차이가 있음을 확인하였다. 이 는 호텔 중간관리자들이 호텔을 평생직장의 관점에서 근속몰입을 하고 있으며 직무에 높은 만족도를 보이고 있음을 의미한다.

넷째, 호텔중간관리자의 직무만족과 충성도 간의 정 $(+)$ 의 인과관계는 지지되지 않았고, 일부 연구결과[8]와 도 차이가 있음이 확인되었다. 그러나 직무만족과 충성 도간의 직접경로에서 직무만족이 충성도에 영향을 미 칠 것이라는 가설이 기각된 것은 직무의 보상적 측면을 강조한 Locke[21]의 주장을 지지하고 있다.

다섯째, 분석과정의 수정지수를 통해 새롭게 발견한 조직몰입과 충성도간의 직접경로는 가장 높은 경로계 수를 나타내며 상관관계가 있음이 확인되었다. 이 결과 는 조직체에 대한 애정과 집착인 조직몰입이 충성도로 연결된다고 주장한 Caruna와 Calleya[16]의 연구와 일 치한다.

따라서 본 연구는 호텔중간관리자층의 업무, 급여, 승 진기회에 대한 만족이 조직 충성도에 연계되지 않는 반 면, 호텔 조직내에서의 평생직장이라는 인식과 소속감 그리고 자긍심이 인지될 때 중간관리자들의 충성도가 매우 민감하게 반응한다는 사실을 확인시켜 주었다. 그 러므로 호텔기업 $\mathrm{CEO}$ 는 중간관리자들의 업무를 서비 스차원의 단순업무로 치부하기보다는 호텔리어의 전문 적인 고유업무로 인식함과 동시에, 중간관리자에게 호 텔업계 최고위관리자층(the top management)으로 성 장할 수 있다는 동기를 부여해 주고 직장내에서 호텔리 어로서의 전문성을 인정받고 있다는 점을 인식할 수 있 도록 자긍심 고취 차원의 경영환경과 인적자원관리에 신중을 기하여야 할 것이다. 또한 호텔 중간관리자층을 전사적 조직운영 및 경영에 참여시켜 자기직무의 중요 성과 필요성을 체감하면서 조직의 성과에 적극적으로 기여할 수 있도록 조직운영체계를 재조정하는 것이 바 람직할 것으로 사료된다.

그러나 본 연구에서는 설문대상지역을 서울지역으로 국한하여 지방호텔 중간관리자들의 의견을 수렴하지 못했다는 아쉬움을 지니고 있는바 후속연구에서 이를 보완코자 한다. 


\section{참 고 문 헌}

[1] 김계수, 구조방정식모형 분석, 한나래, 2007.

[2] 김대권, "호텔종사원 직무만족에 관한 이론적 고 찰", 관광정책학연구, 제6권, 제 3 호, pp.43-58, 2000.

[3] 김영훈, "가맹점주의 직무가치가 직무효과성에 미치는 영향 연구”, 관광학연구, 제 30 권, 제 2 호, pp.279-297, 2006.

[4] 김영훈, "호텔식음료종사자의 직무가치가 직무효 과성에 미치는 영향 연구", 관광연구, 제 22 권, 제 2 호, pp.249-264, 2007.

[5] 김용순, 안대희, "호텔기업에 있어 구조조정상의 공정성 지각이 경영진의 신뢰- 직무만족 및 조 직몰입에 미치는 영향", 마케팅과학연구, 제 18 권, 제1호, pp.115-139, 2008.

[6] 김형섭, "호텔종사원의 직무스트레스, 직무만족, 조직몰입과 이직의도와의 관계에 대한 연구", 관 광연구, 제19권, 제3호, pp.417-427, 2005.

[7] 박대환, "호텔기업 종업원의 서비스지향성이 서 비스 성과, 직무만족과 조직몰입에 미치는 영향", 마케팅사이언스저널, 제 17 권, 제4호, pp.1-22, 2007.

[8] 서영구, 이동한, 김지완, "패밀리 레스토랑 브랜드 의 성적 개성이 고객의 브랜드 자아동일시와 관 계만족 및 브랜드 충성도에 미치는 영향", 관광학 연구, 제32권, 제5호, pp.143-166, 2008.

[9] 오동근, "일 가치감이 직무효과성에 미치는 영향", 한국심리학회지, 제17권, 제3호, pp.375-399, 2004.

[10] 이용기, 유동근, 이대흥, "호텔기업의 시장지향성 과 성과 -직무만족과 조직몰입의 매개적 역할", 관광학연구, 제21권, 제 1 호, pp.49-65, 1997.

[11] 이용기, 이대홍, "호텔 텔레마케팅 관리자의 리 더쉽과 조직몰입”, 호텔경영학연구, 제5권, 제 2 호, pp.178-194, 1997.

[12] 이용탁, "인적자원개발을 통한 직무능력향상이 직무만족 및 조직몰입에 미치는 영향", 인적자원 관리연구, 제14권, 제2호, pp.143-160, 2007.
[13] 이유재, 라선아, "브랜드 퍼스낼리티-브랜드 동 일시-브래드 자산모형 -이용자와 비이용자간 차 이에 대한 탐색적 연구", 마케팅연구, 제 17 권, 제 3 호, pp.1-33, 2002.

[14] 이지우, "근로가치관에 대한 탐험적 연구", 인사 관리연구, 제18권, pp.413-438, 1994.

[15] 함성필, 손선익, "호텔 주방 작업환경이 주방 종 사원의 직무만족 및 조직몰입에 미치는 영향에 관한 연구", 관광학연구, 제32권, 제5호, pp.275296, 2008.

[16] A. Caruana and P. Calleya, "The effect of internal marketing on organizational commitment among retail bank managers," International Journal of Bank Marketing, Vol.16, pp.108-116, 1988.

[17] A. C. Bluedorn, "A unified model of turnover from organizations," Human Relations, Vol.35, pp.135-153, 1982.

[18] A. J. Cellucci and D. L. DeVries, "Measuring managerial satisfaction," A manual for then MJSQ, Technical Report II.

[19] C. Gllisson and M. Durick, "Predictors of hob satisfaction and organizational commitment in human services organizations," Administrative Service Quarterly, Vol.33, pp.61-81, 1988.

[20] D. Elizur and M. Koslowsky, "Values and organizational commitment," International Journal of Manpower, Vol.22, No.7, pp.593-599, 2000.

[21] E. A. Locke, The Nature and Causes of Job Satisfation, in M. D. Dunnett, Handbook of Industrial and Organizational Psychology, Rand McNally: Chicago, pp.231-235, 1976.

[22] J. C. Anderson and D. W. Gerbing, "Structural equation modeling in practice: a review and recommended two-step approach," Psychol Bull, Vol.103, pp.411-423, 1998.

[23] J. C. Nunnally, Psychometric theory, New 
York: McGraw-Hill; 1978.

[24] J. E. Bigne and L. Andreu, "Modelo cognitivo de Ja satisfaccion en servicios de ocio y turismo," Cuad Econ Dir Empresa, Vol.21, pp.89-120, 2004.

[25] J. F. Hair and R. E. Anderson and R. L. Tatham \& W.C. Black, Análisis multivariante, Madrid: Prentice Hall; 1999.

[26] J. H. Steiger, "Structural model evaluation and modification: an interval estimation approach," Multivariate Behav Res, Vol.25, pp.173-180, 1990.

[27] J. P. Meyer and N. S. Allen, "A threecomponent conceptualization of organizational commitment," Human Resource Management Review, Vol.1, p.1, 1991.

[28] J. R. Hackman and G. R. Oldham and K. Ruedu, "A new strategy for job enrichment," California Management Review, Summer.

[29] K. A. Bollen., "A new incremental fit index for general structural equation models," Sociol Methods Res, Vol.17, pp.303-316, 1989.

[30] K. F. Widaman and J. S. Thompson, "On specifying the null model for incremental fit indices in structural equation modeling," Psychol Methods, Vol.8, pp.16-37, 2003.

[31] K. L. Keller, Building, Measuring and Managing Brand Equity(2nd Ed.), New Jersey: Prentice Hall, 2003.

[32] L. T. Hu and P. M. Bentler, "Cutoff criteria for fit indexes in covariance structure analysis: conventional criteria versus new alternatives," Struct Equ Modeling, Vol.6, pp.1-55, 1999.

[33] L. M. Caro and A. M. Garcia, "Cognitiveaffective model of consumer satisfaction: An exploratory study within the framework of a sporting event", Journal of Business Research Vol.60, pp.108-114, 2007.
[34] L. M. Shore and S. J. Wayne, "Commitment and Employee behavior, Comparison of Effective Commitment and Continuance Commitment with Perceived Organizational Support," Journal of Applied Psychology, Vol.78, pp.774-780, 1993.

[35] M. J. Nurosis, SPSS. Chicago, IL: Statistical Data Analysis SPSS Inc; 1993.

[36] M. Whitehead, "Employee happiness levels impact on the bottom line," People Management, Vol.4, p.14, 1998.

[37] R. B. Kline, Principles and practice of structural equation modelling, Jew York: The Guiford Press, 1998.

[38] R. Knoop, "Work values and job satisfaction," The Journal of Psychology, Vol.128 No.6, pp.683- 690, 1993.

[39] R. P. Tett and J. P. Meyer, "Job satisfaction, organizational commitment, turnover Intention and turnover : path analysis based on metaanalytic findings," Personnel Psychology, Vol.46, pp.259-293, 1993.

[40] R. T. Mowday and L. W. Porter and R. M. Steers, Employee-organization links: the psychology commitment absenteeism and turnover, New York Academic Press, 1982.

\section{저 자 소 개}

\section{박 숙 진(Suk-Jin Park)}

정회원

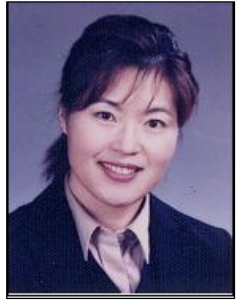

- 2004년 2월 : 경기대학교 대학원 관광경영학과(관광학박사)

- 2004년 3월 2008년 2월 : 한 세대학교 관광경영학과 교수

- 2008년 현재 : 한국관광평가 연구원 연구위원

<관심분야> : 관광정책, 관광자원개발, 문화관광, 연 구조사방법론, 지역경제 
김 태 헌(Tae-Heon Kim) 정회원

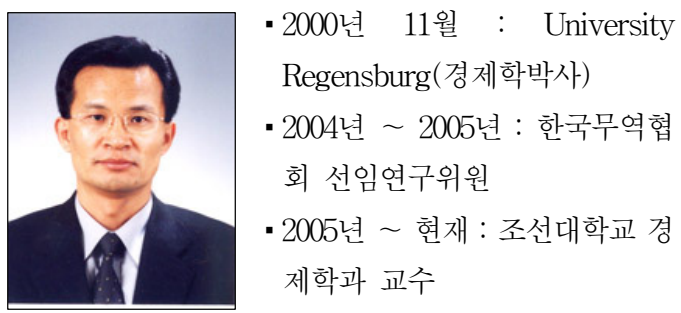

<관심분야> : 경제정책, 국제경제학, 지역경제학 